\title{
E-service Delivery of Union Digital Center in Rural Bangladesh: A Perspective Analysis of Client's Satisfaction
}

\author{
Nusrat Sharmin Khadiza* and Mohammad Nur Ullah \\ Department of Public Administration, Bangladesh University of Professionals (BUP), Mirpur Cantonment, Dhaka-1216
}

*Corresponding author: nusratpa@gmail.com

Received: 09-01-2020

Revised: $12-04-2020$

Accepted: 23-05-2020

\begin{abstract}
This paper basically evaluates the citizen's satisfaction on the e-service delivery of union digital center (UDC) at the grassroots level in Bangladesh. Majority of the people live in rural areas of Bangladesh. Rural local government bodies have been providing them numerous services. Sometimes, rural people need to move to the urban authorities for the faster service as well. The UDC collectively represent and important nexus for service delivery decentralization, local government strengthening, and community empowerment. The centers are enriched with various need-based modern devices. In reality, the quality and the effectiveness of these e-services mostly depend on the satisfaction of the local people and their complement. This study also found that The UDC has relative advantages over alternative service delivery arrangements, and that it has produced positive impacts on bridging the digital divide in Bangladesh. Therefore, UDC faces some serious problems which are also mentioned in the later part of the article with its remedial measures for authority concern.
\end{abstract}

Keywords: E-service, E-Governance, Local Government, Union Digital Center, Client's Satisfaction

E-Governance is a strategic issue that relates to redesigning the national administrative process at the policy-making level to make the Government more transparent, efficient, and service-oriented. It requires high level leadership and participation from all stakeholders (Alam, 2012). In recent years egovernance has emerged as ICT enabled public sector reform strategy to provide information and services to people more efficiently and effectively by reducing time, distance and cost. This policy innovation is also designed to bring more efficiency in the public governance mode through establishing accountable, transparent, hasslefree and participatory administrations (Bhatnagar, 2004). Towards providing e-services to the local people of Bangladesh, The government of the people's republic of Bangladesh launched local digital centers at the countryside of Bangladesh. These centers all over the rural areas of Bangladesh are delivering services to citizens' doorsteps acting as a milestone towards achieving the goals of Digital Bangladesh. The UDCs have enabled rural people to access needed information and essential services in fast, cost effective and easy ways. UDC Census 2013 estimated that about 3.91 million people are receiving information and services from UDCs directly of whom, 949,120 are women (Rahman, 2017). Despite many positive aspects of the Union Digital Centers across the country, there are several negative sides, too.

\section{Objective of the study}

(i) To examine E-service delivery of Union Digital Center at the countryside of Bangladesh. 
(ii) To measure citizen's satisfaction on e-service delivery of Union Digital Center of local government in Bangladesh.

\section{Significance of the Study}

Bangladesh facesseveral obstacles totheeffectivedelivery of public services. Widespread manual processes, resistance to change by civil service and a lack of transparency frustrates citizens in their attempts to avail of government information and services. Opaqueness in service delivery increases the scope for rent-seeking. Government services perform particularly weak in addressing the needs of underserved communities in Bangladesh (Hasanuzzaman, 2013). Electronic services ("e-services") can bring delivery closer to citizens so less money is spent on transportation and less time is spent waiting in lines. Transparency makes management and delivery processes more straightforward resulting in less reliance on rent-seeking middlemen (A21, 2014). With the growing of ICT worldwide, Bangladesh government has already started working with this ICT mechanism. UDC is one of the significant examples of ICT based e-services at the local area of Bangladesh. Although it has already achieved lots of things but it has some limitations too. The worst one is the lack of interest of female entrepreneurs in the rural parts of the country. In some places the problem is so acute that there are no female digital entrepreneurs at all. Another critical issue is developing the perceived needs and benefits of ICTs along with raising awareness about using digital technologies in all possible range of ways in furthering socio-economic development goals. In the wake of massive expansion of ICT based service delivery activities, work of the entrepreneurs has been enhanced to a greater extent but the slow speed internet connection is discouraging them in many times. There are enormous potentialities to make the centers more effective and profitable (Rahman, 2017). However, many grassroots people are not still well aware about UDC and its functions. Because of this, studies need to be taken to find out the basic facilities of UDCs and level of citizen satisfaction on the quality of its services and to give some suggestions for improvement. Therefore, all these things made the researchers interested to conduct this study.

\section{Methodology of the Study}

This study is conducted based on both qualitative and quantitative approach with a view to achieving the research objectives. Both primary and secondary sources of data have been gathered with the intention of fulfilling the research result. The primary data has been collected from local people by using interview questionnaire. The questionnaire contains both structured and unstructured and contingency questions to meet the objectives of the study. Secondary data has been collected from comprehensive literature reviews using current and historical materials relevant to e-service at the local level. Salient literature includes newspaper articles, books, peer reviewed journals, scholarly reports, policy papers, working papers, issue briefs, special reports and various national and international policy documents of renowned research institutions from home and abroad. Purposive sampling was used to collect primary data. Total sample size was 180 respondents covering 10 Union Parishads of Bangladesh. In addition, formal and informal meeting and interview and expert opinion are organized to collect primary data. The UP chairman, UP secretary, entrepreneurs and the citizen/beneficiaries are brought under the interview method for drawing primary information. The data are tabulated and analyzed mathematically as range and percentage. The data collected through observations are also analyzed qualitatively. The computer software program like Ms Word, Ms Excel, is used as tools of analysis and presentation of the survey data in this research.

\section{Theoretical Framework}

E-government implies servicing citizens in public sector via ICT. There are many definitions of e-government in the literature. The most which was cited in most Literature is: "Electronic government refers to government's use of technology, particularly webbased Internet applications to enhance the access to and delivery of government information and service to citizens, business partners, employees, other agencies, and government entities" (Layne, Lee 2001). There are many e-government maturity models in the literature. Maturity models are defined as: "A method for judging the maturity of the processes of an organization \& 
for identifying the key practices those are required to increase the maturity of these processes" (Windley, P. 200). The Gap of this research is that the maturity models in the literature are mainly provider's (technical perspective (efficiency). A new maturity model based on "Citizens' perspective (effectiveness)" is needed.

Gartner Group (Baum and Di Maio, 2000): They proposed a four-stage model involving web presence, interaction, transaction, and transformation.

Table 1: Four Stage Model of Gartner Group

Web presence In this stage, agencies provide a web site to post basic information to public; (immediate action is initiated toward the creation of a virtual environment on the Internet in the Presence stage, in order to provide the public with access to information)

Interaction In this stage, users are able to contact agencies through web sites (e.g. e-mail) or do self-service (e.g. download document); (providing a web site with search ability, and to providing the public with access to various forms and sites)

Transaction

In this stage, users (including customers and businesses) can complete entire transactions (e.g. license application and procurement) online; (implicates the online execution of public services such as the payment of accounts balances and receiving licenses.)

Transformation In this stage, governments transform the current operational processes to provide more efficient, integrated, unified, and personalized service; (the Transformation stage is seen at the regional and national levels, consisting of integration among internal and external applications, in order to provide full communication between the governmental offices and non-governmental organizations)

Source: Bhatnagar (2004).

UN's five-stage model (2001): United Nations and American Society for Public Administration (2001) suggested an e-government model which consists of five stages (efficient web-based public service).
Table 2: Five Stage Model of UN

\begin{tabular}{ll}
\hline $\begin{array}{l}\text { Emerging } \\
\text { presence }\end{array}$ & $\begin{array}{l}\text { A single or a few independent government } \\
\text { web sites provide formal but limited and static } \\
\text { information; }\end{array}$ \\
\hline $\begin{array}{l}\text { Enhanced } \\
\text { presence }\end{array}$ & $\begin{array}{l}\text { Government web sites provide dynamic, } \\
\text { specialized, and regularly updated } \\
\text { information; }\end{array}$ \\
\hline $\begin{array}{l}\text { Interactive } \\
\text { presence }\end{array}$ & $\begin{array}{l}\text { Government web sites act as a portal to } \\
\text { connect users and service providers, and the } \\
\text { interaction takes place at a more sophisticated } \\
\text { level; }\end{array}$ \\
\hline $\begin{array}{l}\text { Transactional } \\
\text { presence }\end{array}$ & $\begin{array}{l}\text { Users have the capability to conduct complete } \\
\text { and secure transactions, such as renewing }\end{array}$ \\
visas, obtaining passports, and updating \\
birth and death records through a single \\
government web site; and
\end{tabular}

Source: UN (2014).

Deloitte's six-stage model (2001): Believing that the purposes of e-government are to serve citizens as customers and to build a long term relationship with citizens, Deloitte \& Touche (2001) proposed a six stage.

Table 3: Six Stage Model of Deloitte \& Touche

\begin{tabular}{ll}
\hline $\begin{array}{l}\text { Information } \\
\text { dissemination }\end{array}$ & $\begin{array}{l}\text { Governments provide users with } \\
\text { increased access to information }\end{array}$ \\
\hline $\begin{array}{l}\text { "Official" two-way } \\
\text { transaction }\end{array}$ & $\begin{array}{l}\text { Agencies are used to provide } \\
\text { interaction between governments } \\
\text { and users by using information and } \\
\text { communication technologies such as } \\
\text { digital signatures and security keys }\end{array}$ \\
\hline Multi-purpose portals & $\begin{array}{l}\text { Governments utilize a single portal } \\
\text { to provide universal service across } \\
\text { multiple departments }\end{array}$ \\
\hline Portal personalization & $\begin{array}{l}\text { Governments enable users to customize } \\
\text { portals according to their own desires }\end{array}$ \\
\hline $\begin{array}{l}\text { Clustering of common } \\
\text { services }\end{array}$ & $\begin{array}{l}\text { Governments enhance collaboration } \\
\text { and reduce intermediaries (between } \\
\text { operational processes) in order to } \\
\text { provide a unified and seamless service. }\end{array}$ \\
\hline $\begin{array}{l}\text { Full integration and } \\
\text { enterprise transaction }\end{array}$ & $\begin{array}{l}\text { An ideal vision in which governments } \\
\text { provide sophisticated, unified, } \\
\text { and personalized services to every } \\
\text { customer according to their own needs } \\
\text { and preferences. }\end{array}$ \\
\hline Source: Alam (2012) & \multicolumn{2}{l}{}
\end{tabular}

Source: Alam (2012). 
In case of Bangladesh from literature review it found that UDCs are providing informational, interactional and transactional services simultaneously.

\section{E-services at Local Area of Bangladesh}

\section{Union Digital Center (UDC)}

Union Digital Centers (UDCs) are micro- enterprises, working as one stop information and service delivery center, since 2010, across all the union parishad, the lowest tier of local government. Each center is run by two villagers or local entrepreneurs- one male and one female. The project is funded by the Government of Bangladesh, UNDP and other development partners, and is implemented by PMO and Cabinet Division. These micro-enterprises are operating under the public private partnership (PPP) model where private sector is performing a key role and working under the supervision of local advisory body headed by elected chairman of each union parishad. It provides both government and private services (Faroqi, 2015). There is broad agreement that these government owned microenterprises are helping to transform sustainability and to transform traditional process of delivering public and private services to the rural citizenry. UDC provides three types of e-services are follows;

\section{Informational service}

For informational services the UDC depends on both online and offline CDs supplied from the project management A2I. One of the major sources of online information for UDC is e-Tathyakosh (electronic information cell) found at www.infokosh.bangladesh. gov.bd. This information hub is user friendly as it encompasses a host of options such as text document, audio, video, animation and picture (A2i, 2015). Though all options have not been equally developed, text document being the dominant, still e-Tathyakosh pulls together enormity of information from various public and private institutions on agriculture, education, health, literature and culture, law and human rights, citizen services, tourism, non-agriculture enterprise, environment and disaster management, science \& information and communication technology, commerce and industry, labor and employment, etc. (Jatiyo e-Tathyakosh, 2014). Local information portal, the Union Parishad Portal, is also created by entrepreneurs in almost all unions that contain information on UP activities as well UDC services. The Jatiya e-Tathyakosh also enables entrepreneurs to links with other government portals for forms download, online applications, e-book download etc. (Jatiyo e-Tathyakosh, 2014). Millions of citizens now have access to authentic government information through the 25,000 websites for all offices of the government and local government. For example, using the hub of digitized forms 'Bangladesh Government Digitized Forms -e-Citizen Services Application' web portal available at www.forms.gov.bd. 440 different kinds of forms for various public services including birth and death registration, driving license, vehicle registration, citizenship certificate, family pension, passport and immigration, income tax return, etc. can be downloaded by entrepreneurs (NWPB, 2014). Other than government forms and some education information there are no other government informational services offered from the UDC for rural citizens.

\section{Interactive service}

40,000 female workers migration registered for overseas jobs. Migrant workers are living with a great vulnerability to exploitation in the host countries. One of the key reasons behind the fact is lack of knowledge behind the negotiation with both the recruiter and the perspective employers. To eradicate the unscrupulous activities of the recruiting agencies, the Bangladesh Bureau of Manpower Employment and Training (BMET) started the process of G2G migration. The job seekers registration was done from the UDCs, CISCs and PISCs of the country (Jatiyo e-Tathyakosh, 2014). In 2013, more than 40,000 female workers registered for the following countries: Hong Kong, Singapore, Jordan and other countries of the Middle East. The working sectors are: housekeepers, garments, nurse, cleaners, factory workers, agricultural workers etc. 1.4 million underserved citizens registered for plantation worker migration in Malaysia. Malaysia started recruitment of Bangladeshi workers in 2006 after 10 years of suspension. During caretaker government in 2007 and 2008, around 
4, 04,963 workers were employed in Malaysia but in an unplanned way within a very short time (Faroqi, 2015). On 26 November 2012, the procedure of workers recruitment under G2G mechanism received renewed attention from all stakeholders. The agreement between the governments of Bangladesh and Malaysia is the first of its kind which formally seeks to promote movement of citizens between the two countries. In order to ensure that such opportunities are not missed by the rural farmers, in particular plantation workers, the Government decided that the registration of the aspirant candidates would take place in a digitized manner through the Union Digital Centers (UDCs). In January 2013, 1.4 million citizens got registered from UISCs for plantation worker migration in Malaysia (A2I, 2015).

\section{Transactional service}

The UDC provides quite a number of transactional services by facilitating payments through locally developed payment software or mobile phone. Such services include land copy, electricity bill pay, mobile banking, admission and job application fees, mobile recharge, etc. (A2I, 2015). In many districts the Pally Biddut Samity (PBS) under the Rural Electrification Board (REB) have made contracts with entrepreneurs enabling them to facilitate easier bill pay for some among approximately $97,25,973$ subscribers across the country. Entrepreneurs can pay bills collected from clients at a nominal fee ( 5 taka) through the mobile provider the Teletalk or through locally developed payment software (BREB, 2014). Similarly, land copies are being provided in some districts through UDCs by allowing entrepreneurs to enter into the District e-service center portal. The payment for stamps and court fees is facilitated through locally developed payment system or through mobile provider or by entrepreneurs visiting the district centers themselves. BRAC Bank's mobile banking unit Bkash signed an MOU with the LGD and A2I to allow entrepreneurs to act as their agents and others are also following the same (A2I, 2014). In terms of expenditure, it is estimated by the Census Report of May 2014 that UDCs spend about BDT 17.34 million per month. This means broadly that UDCs are making a profit of BDT 24.30 million per month and each earning about BDT
$5,410.26$. About $22 \%$ is spent on repairing equipment or buying new equipment. Internet bill and advertisement costs are the two other major expenditure heads. The Census also estimated that 3,859 UDCs are making a profit which indicates their sustainability levels; on the other hand, 633 UDCs are reported to have higher expenditure Vis-à-Vis their earning (UISC census report, August 2014).

\section{Field Data Analysis and Interpretation}

\section{Services of UDC}

Table 4: Citizens taken services from UDCs at least once

\begin{tabular}{|c|c|c|c|c|}
\hline \multirow[t]{2}{*}{ Name of service } & \multirow[t]{2}{*}{ Frequency } & \multicolumn{2}{|c|}{$\begin{array}{c}\text { Percentage of } \\
\text { citizen taken } \\
\text { services at least } \\
\text { once }\end{array}$} & \multirow{2}{*}{ Total } \\
\hline & & $\begin{array}{l}\text { Yes } \\
(\%)\end{array}$ & No $(\%)$ & \\
\hline $\begin{array}{l}\text { Government certificate } \\
\text { (birth/death/citizen) }\end{array}$ & 94 & $52.2 \%$ & $47.8 \%$ & $100 \%$ \\
\hline Application for passport & 8 & $4.5 \%$ & $95.5 \%$ & $100 \%$ \\
\hline Government forms & 5 & $2.7 \%$ & $97.3 \%$ & $100 \%$ \\
\hline Mobile banking & 4 & $2.26 \%$ & $97.7 \%$ & $100 \%$ \\
\hline University admission & 4 & $2.26 \%$ & $97.7 \%$ & $100 \%$ \\
\hline Trade license & 17 & $9.6 \%$ & $90.4 \%$ & $100 \%$ \\
\hline Land recording & 6 & $3 \%$ & $97 \%$ & $100 \%$ \\
\hline $\begin{array}{l}\text { Composing/scanning/ } \\
\text { photocopy }\end{array}$ & 21 & $12 \%$ & $88 \%$ & $100 \%$ \\
\hline Video calling (Skype) & 7 & $3.9 \%$ & $96 \%$ & $100 \%$ \\
\hline Web browsing and e-mail & 11 & $6 \%$ & $94 \%$ & $100 \%$ \\
\hline Computer training & 3 & $1.6 \%$ & $98 \%$ & $100 \%$ \\
\hline
\end{tabular}

Source: field survey.

\section{Comment}

Data shows that people who have come to take service at UDCs, among them, 52.2\% citizen has received citizenbirth/death certificate, $4.5 \%$ has received application for passport application and overseas job application, 2.7\% received govt. form download, $2.26 \%$ mobile banking and online bill payment, $2.26 \%$ university admission information and result check, 9.6\% taken trade license and $3 \%$ have done land recording at UDCs. From other services, $12 \%$ citizen taken composing/scanning/ 
photocopy,3.9\% taken video calling through Skype, 6\% have done web browsing and e- mail and $1.6 \%$ village citizen has taken computer training at UDCs. It is found that the most common service taken by the people is birth or death registration and certificate from UDC.

\section{Reasons behind taking services from UDC}

Table 5: Reasons for using UDCs to receive service than traditional mode

\begin{tabular}{|c|c|c|c|c|c|}
\hline & 1 & 2 & 3 & 4 & 5 \\
\hline Variable & 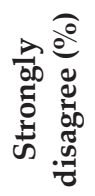 & 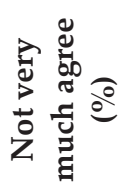 & 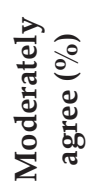 & 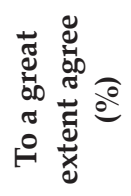 & 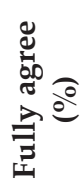 \\
\hline $\begin{array}{l}\text { Cheap in terms of } \\
\text { service charge and } \\
\text { transport cost }\end{array}$ & 17 & 13 & 23 & 38 & 9 \\
\hline Easily accessible & - & 4 & 11 & 83 & 2 \\
\hline No long queues & - & 1 & 38 & 60 & 1 \\
\hline Less rules & - & 2 & 53 & 43 & 3 \\
\hline Quick service & - & 1 & 19 & 76 & 4 \\
\hline Improved service & - & - & 4 & 90 & 6 \\
\hline
\end{tabular}

\section{Source: field survey $n=180$.}

When the question has been asked to citizens that why they are using UDCs to receive service than traditional mode and whether UDCs have been able to fulfill their demands peoples answer was measured in likert scale.

\section{Condition of Services regarding Charge}

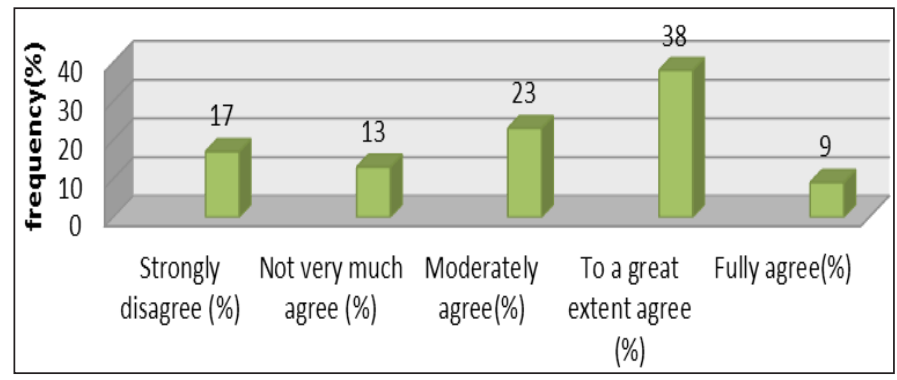

Source: Field Survey

Fig. 1: Cheap in terms of service charge and transport cost

Comment: $17 \%$ respondent has strongly opposed that UDCs has reduced cost, $13 \%$ said that they do not agree much, 23\% said they moderately agree, 38\% said they agree to a great extent and $9 \%$ visitors fully agreed. The above mentioned statistics concluded that the services provided by UDC are cheap in terms of service charge and transport cost than the traditional mode.

\section{Access to the Services of UDC}

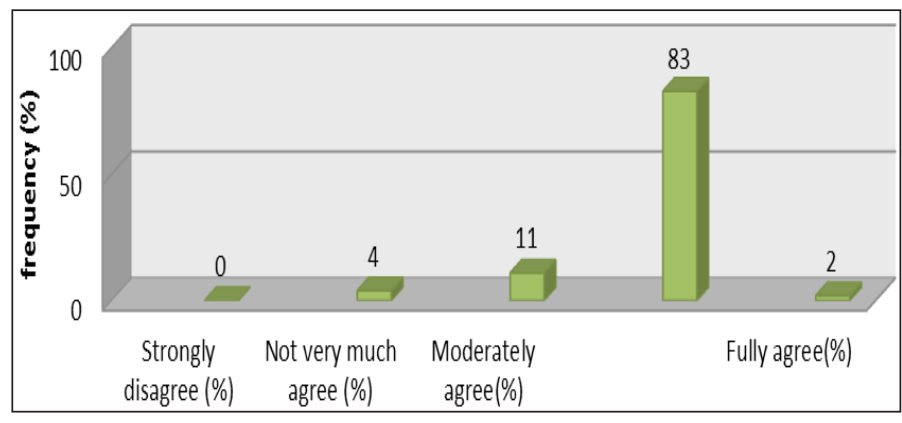

Source: Field Survey.

Fig. 2: Easily accessible

Comment: $83 \%$ respondent has answered that they agree to a great extent that UDCs has made easy accessible to get services, $11 \%$ are moderately agreed, $4 \%$ are not very much agreed, $2 \%$ fully agreed and no one was strongly opposed. It is clear that people are satisfied with the easy access of services provided by UDC than before.

\section{Services of UDC: No long queues}

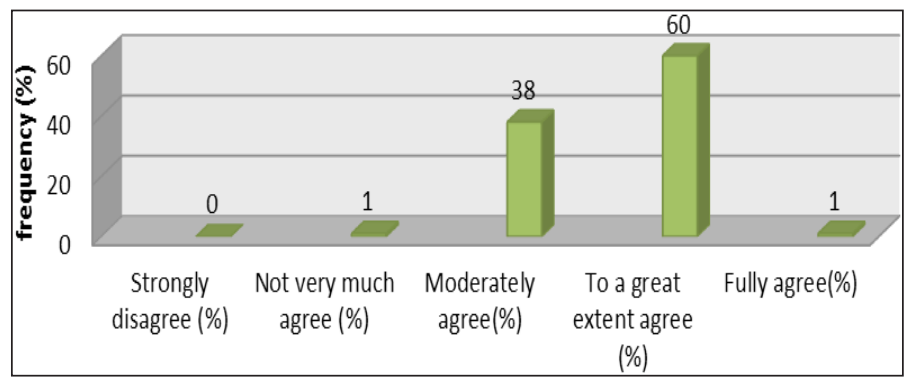

Source: Field Survey.

Fig. 3: No long queues

Comment: $60 \%$ respondent agreed to a great extent that UDCs has reduced long queues in service getting, 38\% moderately agreed, $1 \%$ said not very much agree and $1 \%$ said fully agreed. It is imperative to say, there is no long queues in availing the services of UDC. 


\section{No Complexity to take services and Less Rules}

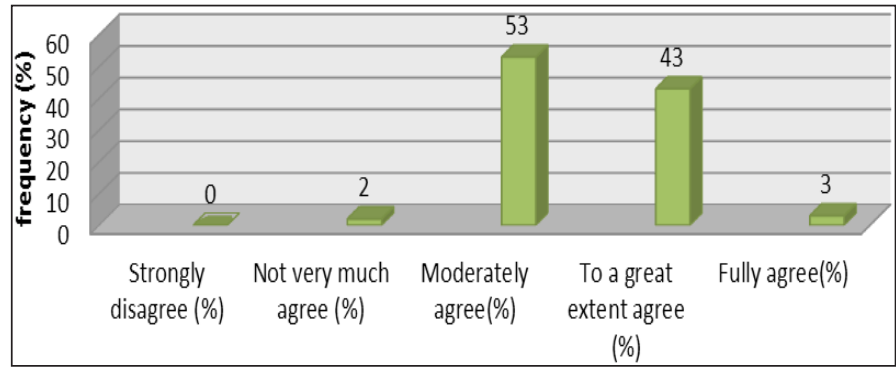

Source: Field Survey.

Fig. 4: Less rules

Comment: whether UDCs has reduced rules and regulation to get government service, 53\% citizen moderately and $43 \%$ agreed to a great extent that rules have been reduced. $3 \%$ said not very much agree with this statement and 3\% said fully agreed with this statement. People are still in fear of narrow game of rules and regulations which encourage to doing corruption and any other illegal activities.

\section{Getting Services in a Quick Manner}

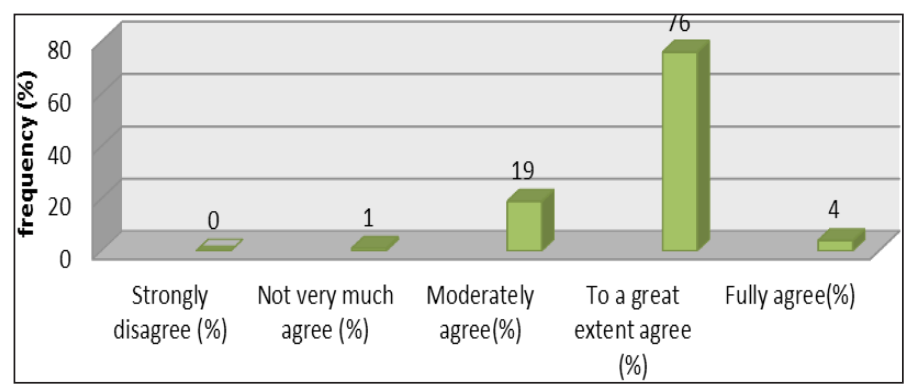

Source: Field Survey.

Fig. 5: Quick service

Comment: $76 \%$ visitors agreed to a great extent that from UDCs they get service quickly, 19\% moderately agreed, $1 \%$ did not agreed much and $4 \%$ visitors fully agreed the statement. The analysis shows that the beneficiaries are getting services of UDC in quick manner than the previous time.

\section{Services of UDC: Analysis of Quality}

Comment: 90\% respondent has agreed that UDCs now provide improved services than previous mode,
$4 \%$ citizen moderately agreed and $6 \%$ fully agreed the statement. The quality of service of UDC is relatively improved, effective and efficient than before.

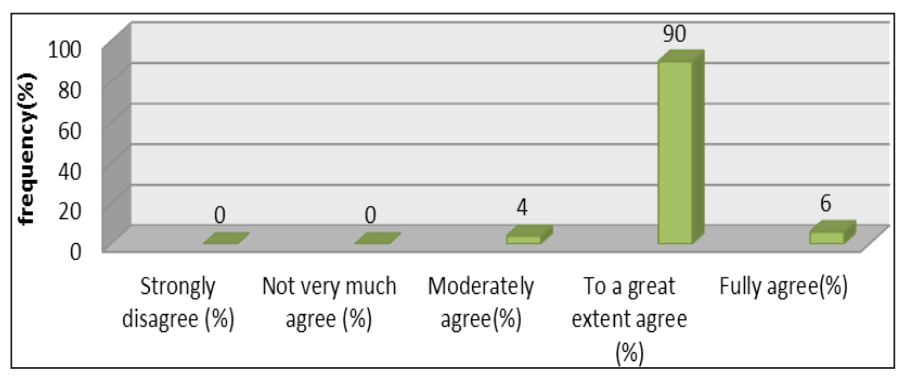

Source: Field Survey.

Fig. 6: Improved service quality

\section{Infrastructural strength of UDCs}

Table 6: Infrastructural strength of UDCs

\begin{tabular}{|c|c|c|c|c|c|}
\hline & 1 & 2 & 3 & 4 & 5 \\
\hline Variable & 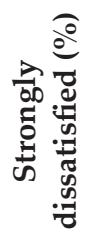 & 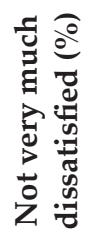 & 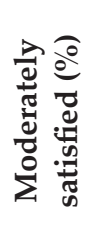 & 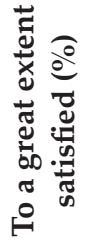 & 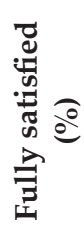 \\
\hline Internet speed & 9 & 12 & 76 & 3 & 0 \\
\hline $\begin{array}{l}\text { Available of necessary } \\
\text { equipment }\end{array}$ & 0 & 4 & 38 & 57 & 0 \\
\hline Availability of electricity & 0 & 13 & 42 & 45 & 0 \\
\hline Skilled entrepreneur & 0 & 0 & 1 & 96 & 3 \\
\hline Behavior of entrepreneur & 0 & 0 & 2 & 89 & 9 \\
\hline
\end{tabular}

Source: field survey $n=180$.

When the question has been asked to citizens about the infrastructural strengths of UDC regarding internet speed, availability of necessary equipment's, skilled manpower, and behavior of entrepreneurs; peoples answer was measured in likert scale.

\section{Speed of Internet}

Comment: $76 \%$ respondent said they are moderately satisfied with the internet speed, $9 \%$ are strongly dissatisfied, $12 \%$ are not very much satisfied and only $3 \%$ are satisfied to a great extent. It is found that people 
are not highly satisfied with the internet speed at UDC, they are moderately satisfied.

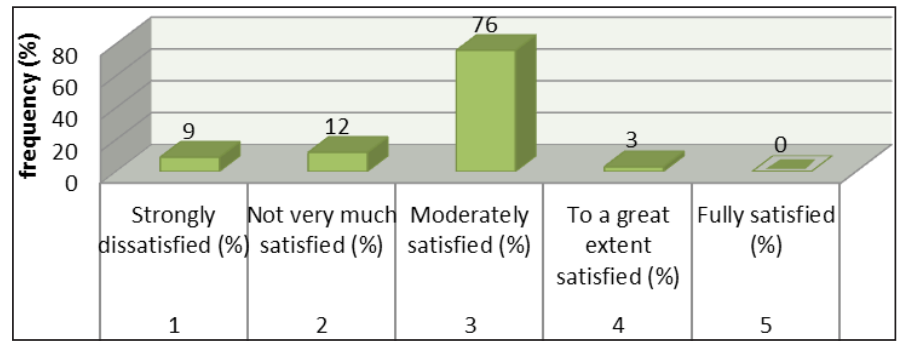

Source: Field Survey.

Fig. 7: Internet speed

\section{Availability of equipment}

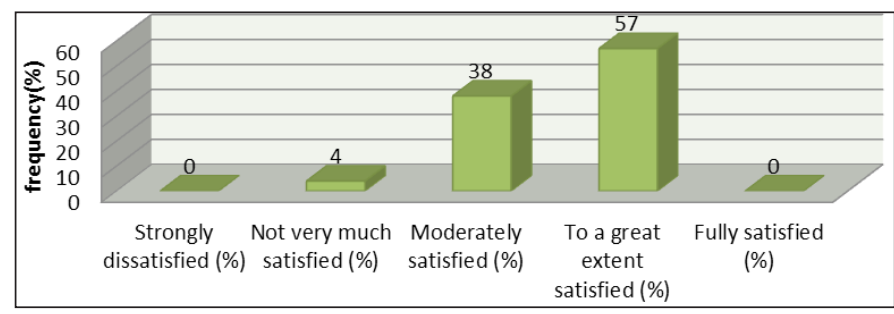

Source: Field Survey

Fig. 8: Availability of necessary equipment

Comment: In terms of necessary equipment 57\% visitors said they are satisfied to a great extent, $38 \%$ are moderately satisfied and $4 \%$ are not very much satisfied. It is noteworthy to say, the equipments are available in most of the UDC but the main problem is in its proper utilization.

\section{Availability of Electricity}

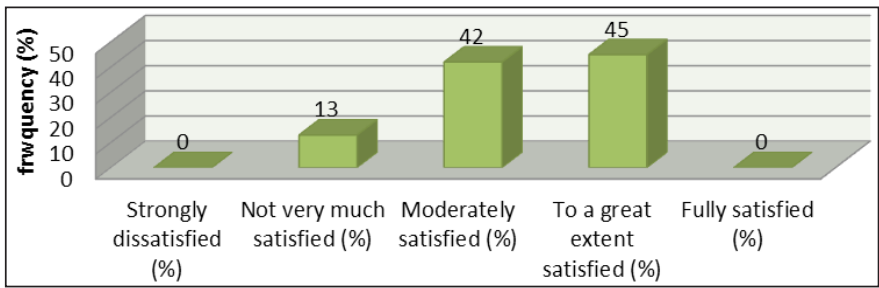

Source: Field Survey.

Fig. 9: Availability of Electricity

Comment: $42 \%$ service seekers are moderately satisfied with availability of electricity, $45 \%$ are satisfied to a great extent and 13\% are not very much satisfied. Statistics shows that the problem of electricity is present in most of the UDC as it is functioning at villages where load shading is still a common phenomenon.

\section{Quality Manpower of UDC}

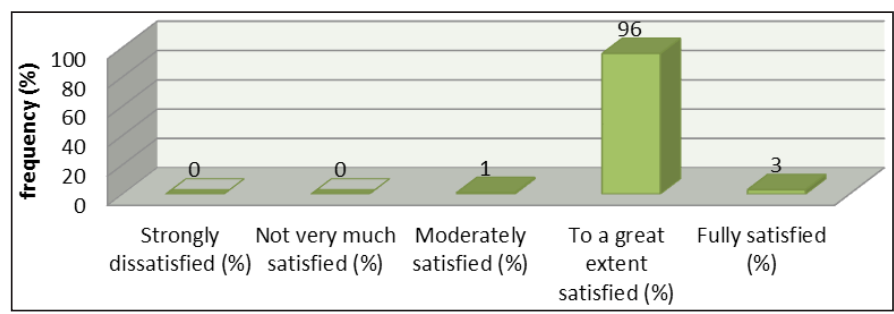

Source: Field Survey.

Fig. 10: Skilled Entrepreneur

Comment: $96 \%$ service seekers are satisfied to a great extent with the skills of entrepreneurs, $1 \%$ is moderately satisfied and 3\% are fully satisfied. In this regard, conclusion is people are satisfied with the skills and expertise of manpower working in UDC.

\section{Conduct of Entrepreneurs of UDC}

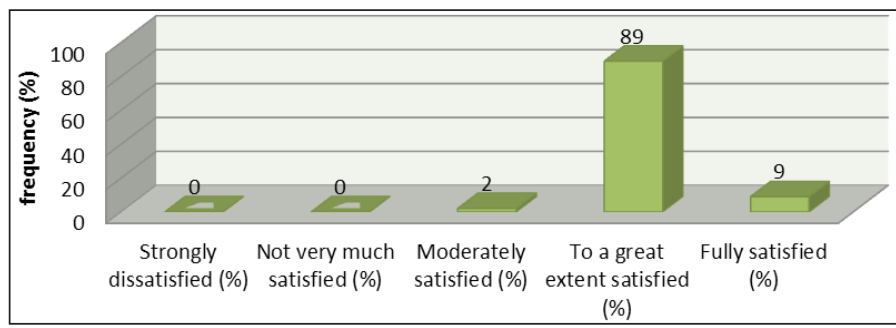

Source: Field Survey.

Fig. 11: Behavior of Entrepreneur

Comment: $89 \%$ service seekers have expressed to a great extent satisfaction with the behavior of entrepreneurs towards citizens, $2 \%$ are moderately satisfied and $9 \%$ are fully satisfied with the conduct of entrepreneurs working in UDC.

\section{DISCUSSION AND FINDINGS}

In the third world counties like Bangladesh the idea of union digital center is very innovative and pioneering. It is one of the noteworthy examples of ICT based 
e-services that can bring service delivery closer to citizens at the local area of Bangladesh. It was started for the first time in 2009 as one-stop information and service delivery outlets to make service available to the doorsteps of underserved people. All over the rural areas the centers are delivering services to citizens' towards achieving the goals of "Digital Bangladesh"; the election manifesto of Bangladesh Awami League (BAL) in 2008. All categories of people are getting benefits from UDCs though educated people are getting more benefits than illiterate people. They have opened the door of modern service to the rural people but the demands for these services are still very low. UDCs have made service delivery process hassle free. When people do not have to travel long distances, spend hours and incur costs which is often unaffordable for them it can be assumed that much of hassles is waned.

Literally, whether the UDC delivery system has made a hassle free service as compared to the alternative delivery system is examined by using both descriptive and test statistics. In the traditional government service delivery system people are often asked for submitting a number of documents to receive services. While some documents are necessary, the excessive ones are not. It is perceived by people that government employees often ask for documents that are actually not required for decision making. Even at times they ask for some of very old and obsolete documents that are hard to collect by service recipients. The UDC is set to free people from these extra hassles and ask people for documents that are really needed for decision making.

Usually, it does not ask for documents other than for government services. The UDC is also a quickwin project to address the issue of digital divide. It is introduced in the context of imbalances between three components of e-government, i.e. online component, telecommunication infrastructure and human capital that poses a potential risk of digital divide. The UDC as a shared access point founded on the PPP approach can thus be assumed to have impacts of bridging the digital divide that runs through gender, age, levels of literacy, income, geographical locations etc. Though the participation of rural people in commercial and internet based service is very low but the thing is that people have learned about these service only lately so it can be expected that once people understand their utility they will be able to take the full advantage of it.

\section{CONCLUSION AND RECOMMENDATION}

As we have seen that there is a number of information and services offered through the UDC to the rural people in Bangladesh. While some of them relate to their livelihood issues such as land record copy and education information and services, there are no services related to agriculture. The inadequacy of services, especially the government ones such as land copy, electricity bill pay, mobile banking is not available at all UDCs. Despite such limitations the UDC has proved that it has the potential to reduce time, distance and cost in service delivery given the presence of cost opportunity services. Its delivery mode is hassle free, immune from the reign of intermediaries and it does not ask for extra documents or coerce with bribes. The provider is empathetic to the recipients since he has to live by means of earning from customers. Therefore, people value the UDC more compared to the alternative delivery points. The UDC has achieved some gains in bridging the digital divide in dimensions such as gender, education, occupations and income. Though women participation is more in the UDC compared to traditional points, their participation for certain services still did not happen. Similarly illiterate people's participation is also low since there are no special services for them. The service delivery role of the UDCs has remained limited largely because they are yet to be connected to back end government agencies that would supply e-government services. The few e-government services provided by UDCs are mainly done by connecting themselves with websites of relevant government agencies. However, followings are some recommendation for UDCs based on this study;

* UDCs can be instructed to introduce services on agriculture and livelihood.

* Availability of electricity should be ensured and more solar systems should be provided to the entrepreneurs.

* Internet speed should be improved and cost should reduce. 
* Entrepreneurs should advertise the facilities of UDCs in a greater number.

* Land recording, mobile banking services should be introduce in all UDCs.

* National identity card correction and all types of government job application and money deposit system should introduce at UDCs.

* To do many government activities proper standardization of Bengali software should be done.

* Entrepreneurs and govt. should motivate public to use govt. websites rather than traditional methods.

* Adequate resources must be made available.

\section{REFERENCES}

Access to Information (A2I) Program, (2011), 'Bangladesh: Access to Information (A2I) Evaluation - A Report prepared for United Nations Development Program (UNDP)', Dhaka: Prime Minister's Office.

Access to Information (A2I) Program, (2014), 'Initiatives: Union Information and Service Centers (UISC)', Dhaka: Prime Minister's Office.

Access to Information (A2I) Program, (2015), 'Initiatives: Union Digital Centers (UDC)', Dhaka: Prime Minister's Office.

Alam, Mohammad, Jahangir, (2012), 'E-Governance in Bangladesh: Present Problems and Possible Suggestions for Future Development', International Journal of Applied Information Systems (Ijais), 4(8): 66-75.

Bhatnagar, S. (2004). E-Government: From Vision to Implementation - A Practical Guide with Case Studies. New Delhi: SAGE Publications India Pvt. Ltd.

Bhatnagar, S. 2009. A Framework and Methodology for Impact Assessment', in Unlocking E-Government Potential: Concepts, Cases and Practical Insights. New Delhi: Sage Publications.
Faroqi, M.G. and Siddiquee, N.A. 2011. 'Limping into the Information Age; Challenges of E-Government in Bangladesh', Journal of Comparative Asian Development, 10(1): 33-61.

Faroqi, M.G. 2015. 'An assessment of e-government: case study on union digital centers (udc) in Bangladesh', Australian Journal of Sustainable Business and Society, 1(1): 33-42.

Hasanuzzaman, 2013. 'Role of UDC in online registration of overseas job seekers', Retrieved from The Daily Sun, Dated January 22, 2013.

Heeks, R. 2003. Success and Failure Rates of e-Government in Developing/Transitional Countries: Overview. University of Manchester.

Hussain, F. 2008. 'Effectiveness of Technological Interventions for Education and Information Services in Rural South Asia', A Doctoral Dissertation in Carnegie Mellon University USA.

Jabbar, M. 2009. Digital Bangladesh. Dhaka: Ananda Publishers.

Jatiyo e-Tathyakosh. 2014. Home, A2I, Dhaka, Bangladesh.

Lallana, Emmanuel C. (2002). E-Government in the Philippines: Benchmarking Against Global Best Practices.

Layne, K. and Lee, J. 2001. 'Developing fully functional e-government: A four stage model', Government Information Quarterly, 6(18): 122-136.

Rahman, Bappy, 2017. ‘Union Digital Centre: Reaching E-Services to Rural Citizens' Doorsteps', Retrieved from the daily sun on 21 November, 2017.

Sarker, A.K. 2013. Digital Bangladesh: Swapna Puroner Ovijatra ( $A$ Journey to fulfil Dreams). Lalmatia: Tothyoseba Barta Songstha (TSB) Publisher.

Transparency international Bangladesh (TIB), 2012. 'Corruption in Service Sectors: National Household Survey 2012', Dhaka, Bangladesh.

United Nations (UN) 2014. 'E-government Survey- E-Government for the Future We Want', New York: Economic and Social Affairs. 